\title{
A Study on the Normalization and Institutionalization of "Two Studies, One Action" in Functional Party Organizations in Universities
}

\author{
Qiu-Di ZHAO*
}

\author{
37 Xueyuan Road, Beihang University, Beijing, China \\ Email: zhaoqd@buaa.edu.cn
}

\begin{abstract}
Keywords: functional party organization in universities, "Two Studies, One Action”, normalization and institutionalization

Abstract: The functional Communist Party organization in universities is represented by college apartments and student associations, which are important platforms to keep close contact with young student Party members in universities. Making full use of this platform to carry out "Two Studies, One Action", refers to the "To study Party Constitution, Party regulations, and related major policy addresses and to meet Party standards" learning and education activity extensively and deeply is an important content to promote comprehensive and strict Party governance. In this paper, based on the connotation of the functional Party organization of universities and the requirements of the "Two Studies, One Action", studying around the normalized and institutionalized education, the author puts forward basic principles about promoting "Two Studies, One Action" in the functional Party organization, clarifies the relationship between functional Party organization and Party construction, summarizes historical experience, draws the Party beneficial results, and based on the basic principle in this paper, put forward the implementation path about promoting "Two Studies, One Action" learning and education activity in the functional Party organization in universities.
\end{abstract}

\section{Introduction}

Study and implement thoroughly the important spirit of President Xi Jinping's speeches can promote strict Party governance to a new level, advance the Party's ideological, political and organizational development, and maintain the Party's progressiveness and purity. The Party central committee has decided to carry out "To study Party Constitution, Party regulations, and related major policy addresses and to meet Party standards" learning and education activity, among all Party members in 2016, namely "Two Studies, One Action". Since the 18th National Congress, Xi Jinping stressed several times the Party's construction, during the "Two Studies, One Action" learning and education activity, Xi Jinping made important instructions to implement it. "In order to promote inner-Party education from key minority to the broad masses of Party members, from centralized education to the regular education, determined the general Party member's Marxist position, keep the Party always ideological political actions on the central keep highly consistent, and make our Party always have ideal, belief of Marxist Party." ${ }^{[1]}$

\section{The connotation and characteristics of functional Party organizations in universities}

\section{(I) Connotation}

The functional Communist Party organization in universities is a new and special Party organization based on the characteristics of social development, industrial transformation, and the distribution of party building resources, through integrating scientifically the resources of Primary-level Party organizations in order to realize the redistribution, recombination and re-optimization of party organization resources. The basic requirement of this organization is to set up different forms of party organizations to meet the needs of party members. The ultimate task of this organization is to spread the ideas of the Communist Party among the masses. A functional Party organization with "interest", "region", and "work" as a link is conducive to promoting the openness of the organization and the initiative of its members.

The functional Party organization in universities is an important platform where the Party in 
the universities contact closely with young student who are Communist Party members. This article takes university dormitories and associations as research objects, and sets up a Primary-level Party organizations platform with professional function and clear political orientation in colleges according to universities' training goals. This organization can help students better understand party policies through flexible forms and innovative methods. Moreover, this organization can better evaluate the political level of students through the performance of daily life. Let young students regularize and institutionalize the requirement for all Party members to study the Party Constitution, Party regulations, and President Xi Jinping's major policy addresses and to meet Party standards. At the same time, through this platform, young students can use their expertise to serve the community and help others.

\section{(II) Characteristics}

1. In student apartments

(1) Students stay for a long time, student housing is an important position for ideological and political education.

Apartment is the first society, the second family and the third class where students enter the university life for the first time. The period of university is a crucial period for the formation of students' ideology, outlook on life and values. The cultivation of ideology and morality and the cultivation of good habits are imperceptibly influenced by the bit by bit life in the apartment. The functional Party organization represented by the apartment plays an important role and has the characteristics of long-term stability.

(2) It is convenient, frequent and operable to carry out Party activities in the apartment.

In the apartment and the dorm to carry out the activities of the Party, save time, reduce the burden of the students in addition to participate in the activities of the Party organization, bringing great students share their experiences in learning and sharing comprehension, closely integrated with common daily life, on the basis of the traditional learning activities, explore the apartment "Two Studies, One Action" long-term mechanism, has a great operability.

(3) The family and social attributes of the apartment are conducive to comprehensive student evaluation.

Apartments are like a miniature society where relationships can be reflected. The relationship between housemates and the behavior in one's daily life are representative and authentic. The dedication of party members in the apartment can promote a good atmosphere in the student apartment. At the same time, it can also help everyone better understand the meaning of society and family.

(4) It is conducive to promoting students' self-management, self-service and self-development.

The student party organization in the apartment or the student self-discipline management organization based on the party organization can hold a joint meeting with the community party branch to discuss the major issues of community life to serve the students. For example, negotiate and solve some common health environments, security risks, traffic order. Youth party members in the apartment can take the initiative to care for the surrounding classmates, resolve some contradictions in the dormitory, and find psychological crises and abnormal conditions in time.

2. Establish primary Party organizations in student associations

(1) Gather together due to interests and have strong cohesion.

Student clubs are a collection of students with the most common interests and strengths in various majors and industries. Students join the club out of their own strong interest, with spontaneity and initiative, which makes the club strongly cohesive. The establishment of functional Party organizations in student associations can effectively improve students' participation in the political life and activities of Primary-level Party organizations Party organizations.

(2) Take club activities as the carrier and actively practice "Two Studies, One Action".

Student associations as the most vitality and vigor of organization, usually in the weekend, summer and winter vacations will based on expertise in the field of social across various industries to carry out practical activities, from the model aircraft games, robot teaching to social hot spot 
research, community volunteer service, from domestic to overseas, time span is big, wide coverage, there are different forms of activities. The establishment of functional grass-roots Party organizations in the community can give full play to the characteristics of the diversity of community activities, combine the Party's theoretical thought with practical behavior, experience in practice, spread in practice, investigate in practice, and cultivate young students' sense of social responsibility and mission.

\section{The goal and the request to implement "Two Studies, One Action" the learning and education activity in term of normalization and institutionalization in the functional Party organization}

\section{(I) Overall objectives and requirements}

Functional organization due to its own features and existing form, has strong flexibility to implement "Two Studies, One Action" study education activity. Fully based on the pursuit, starting from the content, fully playing the characteristic functions of party organizations to merge the Party spirit and functionality of the functional Party organizations.

In his speech at a conference celebrating the 95th anniversary of the founding of the Communist Party of China (CPC), President Xi Jinping put forward that "we should uphold the fighting spirit of the Party's founding members and their commitment to the people." ${ }^{[2]}$ As a Party member, we should keep in mind the new requirements of for Party members, keep in line with the Party Central Committee in political ideology and theory, adhere to the purpose of the Party, and make contributions to the Party and the country. Returning to the innovative Party building form of functional Party organization in universities, we should take the manifestation of Party spirit as the traction, highlight the functional characteristics of the organization, and improve the ability and level of serving the society, serving the people and promoting development.

On April 16, 2017, the symposium on the normalization and institutionalization of "Two Studies, One Action" learning and education was held. President Xi Jinping made important instructions and emphasized that "Two Studies, One Action" learning and education has been carried out throughout the Party, and remarkable results have been achieved. Practice has proved that learning and education through "Two Studies, One Action" is a powerful force for building the Party on ideology, organization and govern. ${ }^{[3]}$ To forward the "Two Studies, One Action" learning and education to be normalized and institutionalized, on the premise of Party building, we should stick to President xi as the core of the CPC central committee leadership, keep and exert the inevitable request of the Party's political advantage, which is conducive to deepening the Party's education, to continue to strengthen the Party's construction, and has great significance to develop the socialist cause with Chinese characteristics to the new situation. Advance "Two Studies, One Action" learning and education to be normalized institutionalized, we should give first priority to ideological education, insist on President Xi's series of important speech spirit, insist on combining study, unity, the implementation of Primary-level Party organizations, wake up the Party members' vanguard consciousness, and set up the leading role.

\section{(II) Specific goals and requirements of functional Party organizations in universities}

Primary-level Party organizations represented by functional Party organizations in universities should not only understand the content of "Two Studies, One Action", but also constantly explore and carry out effective measures. "Two Studies, One Action" is based on learning, but the key of which is doing. This is not only a theoretical problem, but also a practical problem. Functional Party organizations rely on college student apartments and student associations, integrating theoretical learning into daily life, focusing on the regular, and embodying practical activities in all aspects of life, so as to integrate knowledge with practice. Using the functional Party organizations in universities to form a good atmosphere of "learning the Party constitution and rules, learning a series of speeches, and becoming a qualified Party member". The normalization of "Two Studies, One Action" guarantees the quantity, changing learning and education from intensive to regular, to form long-term learning. Institutionalization is the guarantee of the quality, which makes "Two 
Studies, One Action" develop in a standardized and scientific direction. ${ }^{[4]}$ The combination of normalization and institutionalization will make the implementation of functional Party organizations more standardized and efficient.

In universities, considering with students' study and life conditions, the functional Party organizations can more often organize students to study President Xi Jinping's speeches and insist on learning other theoretical knowledge of the Party. A mature system is gradually formed in regular organizational life, so as to ensure the constant implementation of "Two Studies, One Action". At the same time, assessing young Party members in the daily life is more objective and authentic. We should guide young Party members in their daily lives to make them to be qualified for politics, discipline, morality, and performance, and to be closer to the standards the Party needs in constant efforts. ${ }^{[5]}$

Functional Party organizations can better play the vanguard and model role of young Party members. In the apartments and associations where students often take part in activities, Primary-level Party organizations are established to integrate ideological education into daily life and activities, so that "Two Studies, One Action" would no longer become an additional burden in the daily life of students, so that there are people around to supervise, so that the behavior quality is comprehensively evaluated. In addition, exerting the role of youth party members can promote other students' progress towards higher standards.

\section{The principle and path of the normalization and institutionalization of "Two Studies, One Action" in functional Party organizations of universities}

"Two Studies, One Action" learning and education activity is the main political task of the Party construction work in universities. Universities shoulder the important function of training talents. In order to maintain the normalization and institutionalization of "Two Studies, One Action", functional Party organizations in universities must first lay theoretical foundation and logical premise. At the same time, we should pay attention to the summary of the historical experience from the Party's historical practice and the Party's fine tradition, to draw useful experience in the construction of functional Party organizations in universities, and integrate it into the construction.

\section{(I) The basic principle}

1. Clarify the relationship between university Party building and functional Party organizations, and establish the logical starting point for the development of functional Party organizations in universities

To further promote the development of the Party's ideological and political construction, the CPC Central Committee made important instructions on "Two Studies, One Action" and advancing its normalization and institutionalization, to make the Party construction more strong. The functional Party organization by conducting "Two Studies, One Action" learning and education, can help the Party members to carry out the ideological and political communication, armed with President Xi's series of important speech spirit, in order to comply with the Party constitution as the basic requirements. It could give full play to the functional features of the Party organization of universities, guarantee effectively the different types functional Party organization function, and strengthen the relationship between the Party and the masses. We should earnestly implement the important instructions of "Two Studies, One Action", and integrate theoretical learning and practical activities into the functions of the functional Party organizations in universities. As Beihang University's activities, "beautify the apartment" on the thematic Party day, we launch the student Party members and student representatives to participate in this compulsory labor, to help clean up the students' apartment staff dormitory balcony, and organize bicycles in the parking area, etc. Through the platform of apartment of functional Party organization coordination, the students from different grades are promoted to play their own advantages roles in apartment living and activities, both in spreading the "labor glorious" good atmosphere and giving full play to the highlighting features and functions of the different majors, to better promote scientific management and strengthen the service sector and students to understand and support each other. 
2. Summarize historical practical experience and draw useful results from Party building

It is a fine tradition of our Party to make every effort to do a good job in Party building. To promote the great new project of Party building, the functional Party organizations in universities must constantly summarize historical experience and draw useful lessons from historical process. We will use the professional resources and distinctive advantages of all walks of life, fields and levels to provide the people with support that is within our capabilities and essential. In the history of the Party, the various tasks led by the whole Party during the Yan 'an period have fully reflected the distinctive characteristics of functional organizations. The Party served necessary social functions in a flexible organizational form, and provided sufficient social security. During the Yan 'an period, with the construction of base areas, the educational cause also achieved unprecedented development. The establishment of a number of educational institutions provided a basis for the generation of functional party organizations in the higher education front.

To promote the normalization and institutionalization of "Two Studies, One Action", we must pay attention to inheriting and carrying forward the spirit of Yan 'an. Yan 'an Rectification Movement has important inspiration on the "Two Studies, One Action" implementation. The functional Party organization and the "Two Studies, One Action" learning and education must be based on its own characteristics, clarify relationship between the college Party construction and the functional Party organization, summing up the experience in the past to push forward development of "Two Studies, One Action" and promote effectively the Party continued stable development.

(II) The methods and ways to normalize and institutionalize "Two Studies, One Action" in functional Party organizations of universities

1. Put education first and integrate it into daily work

"Two Studies, One Action" is normalized and institutionalized, with the primary emphasis on ideological education. Therefore, it has become the important responsibility of various functional Party organizations in universities to deeply understand the spirit of President Xi Jinping's important speeches and to constantly regulate themselves with the Party constitution and rules. Party members should take questions to study, enhance the Party spirit and service consciousness. Party organizations should be good at setting up advanced models and absorbing positive energy to comprehensively improve the effectiveness of the organization. What is more important for the functional Party organizations in universities is the innovation of ways and methods to make breakthroughs in learning and application. For example, the "one-day dormitory administrator" activity takes the function of the Party organization as a platform, allowing students to participate in the daily management service of the apartment as the dormitory administrator. Build a social practice platform for students, enhance the understanding and communication between management service providers and students, and strengthen mutual support and cooperation. With the functional Party organization of universities as the platform, students of different colleges are encouraged to carry out various work experiences, so that students have a new understanding of apartment management services. Through personal experience and changing roles, students can change their thinking to solve problems from the perspective of managers. Through practical experience, students can deeply understand the difficulty of ordinary and trivial work of logistic support service, as well as the important mission of keeping students' accommodation safe at all times. It not only promotes students' understanding and identification of apartment management, but also promotes student Party members' support and cooperation for apartment management in functional Party organizations.

The functional Party organization in universities should adhere to the unity of learning, thinking and practice, attach importance to inner-Party education, arm the students' mind with advanced theory and guide practice. By steadily promoting the normalization and institutionalization of "Two Studies, One Action", we could put "learning" and "doing" into life and work to ensure the "Two Studies, One Action" continued system. Regularly studying of Party courses in functional Party branches can lead Party members to promote the learning progress and improve the learning results. To fulfill "Two Studies, One Action", the functional Party organization 
can make full use of their own advantages, such as call on students to go to countryside to carry out the theoretical explanation, medical services and diversification of loving service activities such as artistic performance, which can inspire the student Party members the steadfast to be a qualified Party members.

In all, functional Party organization in universities can promote the "Two Studies, One Action" to be normalized and institutionalized. And the "Two Studies, One Action" learning and education activities can be combined with the daily life and work. Then, we can just focus to learning in Party class. In addition, we can regularly carry out "two studies and one action" based on the construction of school apartment culture and community activities.

2. Use new media to promote "two learning and one action"

In the era of increasingly rich information technology and new media, based on the continuous expansion of Internet application, the construction and development of functional Party organizations in universities should increase the use of new media and Internet. Based on the traditional experience, new approaches should be explored and diversified channels should be adopted to practice. By taking advantage of the technical advantages of the young and middle-aged student Party members in functional Party organizations in universities, the WeChat public account of Party members' learning and education is established in universities to expand the media coverage and increase the convenience of Party members' learning and education. MOOCS are implemented on the internet platform, so that students can not only study independently online, but also set up study groups based on apartments and communities in the "learning power APP" to facilitate online discussion and interaction of functional Party organizations. Through "video" publicity, the public's perception of Party organizations can be enhanced. And Party members also can use multiple forms such as audio, video, and film to carry out the Party members' education interest activities, to improve the appeal to the student groups as well as promote "Two Studies, One Action" learning and education in universities. Renmin University of China carried out the "Party" micro video panorama shooting ordinary life about students, teachers and line management services, which took advantage of the college Party organization's professional and technical advantages to expand the influence study topics covered scope, but also give full play to the function of Party organization propaganda lead.

3. Strengthen organizational leadership and implement principal responsibilities

To carry out "Two Studies, One Action", we should strengthen the leadership of Party organizations and take it as a political task to be completed earnestly. In universities, we should take the initiative to integrate "Two Studies, One Action" into the learning activity system of functional Party organizations and carry out learning and education activity regularly. Functional Party organizations at all levels should formulate work plans, carry out study discussions and work reports, and carry out comprehensive education and guidance for Party members based on their own functional attributes. Leaders of functional Party organizations in universities should play a leading role, take the lead in demonstration and practice to promote the normalization and institutionalization of "Two Studies, One Action" learning and education in functional Party organizations in universities.

4. Seek truth from facts and establish a long-term mechanism

For Party members, they should always use the Party constitution and Party rules to regulate themselves in practice, timely find their own problems and effectively solve them. Functional Party organizations in universities should grasp the requirements of "Two Studies, One Action", and keep the activities of functional Party organizations in universities regular on the basis of close contact with their own reality. On the one hand, promoting the leaders and members of functional Party organizations in universities to go deep into life, finding problems in time and promoting the function of Party organizations by self-reform and self-improvement of Party organizations can make the characteristics of functional Party organizations be fully reflected in students' life and study. In carrying out organizational activities, functional Party organizations should constantly check whether they have strictly adhered to the Party's line, principles and policies, whether they 
have implemented the requirements for strict Party governance, and established a system for solving problems.

The functional Party organizations in universities should earnestly implement the Party's thoughts and concepts, strengthen Party spirit education, and strengthen inner-Party democratic political construction. While strengthening self-education, Party organizations and Party members should focus on the practice of serving the masses and reflecting their own functional value, and take the actual effect of serving the masses as the judgment standard of Party spirit education.

\section{Summary}

The functional Party organization of universities should persist in seeking truth from facts and solve pressing problems at the grassroots level. The functional Party organization "Two Studies, One Action" can promote the further development of governing Party and more focus of reality, as well we provide strong support for the cause of socialism with Chinese characteristics. "Two Studies, One Action" is a big innovation in the process of the Party's ideological and political construction, the construction of functional Party organizations in universities is also major innovation in the development of the Party organization construction, which can promote the normalization and institutionalization of the learning and education activity, "Two Studies, One Action".

\section{Acknowledgment}

This research was financially supported by the Party Construction Research Support Project of Beihang University "Study on the normalization and institutionalization of "Two Studies, One Action" learning and education in the functional Party organizations in universities"

\section{References}

[1]Information on http://www.xinhuanet.com//politics/2016-02/28/c_1118181541.htm

[2]Information on http://news.china.com.cn/2016-07/01/content_38789860_2.htm

[3]Information on http://www.xinhuanet.com//politics/2017-04/16/c_1120819306.htm

[4]Xu Jiaxin. Correctly grasping the relationship between normalization and institutionalization and carrying out "two studies and one action" learning education [N]. People's court newspaper, 2017-09-18(002).

[5] Information on http://www.xinhuanet.com//2017-03/28/c_1120711368.htm 